\title{
POSSIBLE REASONS WHY ESP IS UNDER RECOGNIZED IN ACADEMIA
}

\author{
Nadežda Stojković \\ Faculty of Electronic Engineering, University of Niš, Serbia \\ E-Mail: Nadezda.Stojkovic@elfak.ni.ac.rs
}

\begin{abstract}
Hereby the claim is presented that among adult population of learners of English language in academia and life-long learning formats, the predominant approach in English Language Teaching (ELT) needs to be English for Specific Purposes (ESP), since General English has mostly been mastered by then, and because those learners then need linguistic training that would enable them to upgrade their professional efficacy and so remain competitive as demanded by contemporary professional/scientific global community. Nonetheless, such relevance of ESP for adult learners has not yet been recognized by main stakeholders in the field of ELT, namely academia and most famous ELT textbooks and reference books publishing houses, leaving ESP practitioners still on their own regarding professional development. This general overview is an attempt to rationalize the reasons for this paradoxical situation.
\end{abstract}

Key words: English for Specific Purposes, adult learners, professional domain language, educational policies, publishing houses policies

\section{BENEFITS OF ESP INSTRUCTION FOR ADULT LEARNERS}

Among the adult learners of English as a Foreign Language (EFL), starting from faculties onwards (employed professionals, specialist trainings, etc.), General English (GE) courses do not suffice as by that time those learners have already mastered English to the extent they can communicate with ease. At that stage, what they do need, and what has not been taught in their previous education is English for their profession or academic research or job positions. For this reason, at tertiary educational level, English language courses offered deal with English as used in the specific domain - the ESP courses, rather than GE courses (Mackay \& Mountford 1978). The reasons why adult population, beginning with students at universities, learns English language, are the requirements of their profession. That implies that there are definable characteristics of the globalized nature of the given professional and scientific research strands, crucial linguistic abilities typical of a certain professional environment and sets of standardized academic skills. ESP instruction is in its essence a linguistic simulation of the content and relevant language skills of a particular professional and/or scientific environment, devoted to linguistic practicing of the conventions of that reality, and so is a tool for building and perfecting professional domain language skills needed for the successful participation into the global economy of today.

Submitted September $9^{\text {th }}, 2019$, accepted for publication November $9^{\text {th }}, 2019$ 
ESP as profession and science oriented form of ELT, subsumes minute segmentation of such courses, specifically tailored for a particular, usually small group of students. Practitioners are required to make or design a selection of linguistic traits in terms of specific lexis, semantic structures, morphology, and the like, that are most present in their students' target professional setting. Most often, there is no ready-made teaching/learning material available, as learners' needs are specific to the point of being idiosyncratic. What is taught, for example at one faculty, may not be entirely applicable at another one, even of the same profile, simply because the latter being in another geographical and therefore economic area where prospective job positions significantly differ. This leaves the lecturers of ESP completely on their own as regards the development of teaching material. In the literature on the theoretical basis of ESP, its practitioners are said to have five key roles (Dudley-Evans and St John 1998), namely of a teacher, course designer and material provider, collaborator, researcher, evaluator. All of this reinforces another ESP theory basic stance - its practitioners "dwell in a strange and uncharted land" (Hutchinson and Waters 1987).

\section{SPECIFICS OF ESP LECTURER'S PERFORMANCE}

Here we shall briefly remind of the complexity of such position. ESP professionals need first to ponder into a science they had no training in, mostly on their own. After getting an academic education in English language and linguistics, they are forced to start discerning, learning about a science they may have no real personal interest in, no previous or even general knowledge about. It is from here, and only after gaining such insight, that an ESP lecturer can proceed to distinguishing the most prominent linguistic, semantic, morphological features of the given professional discourse. This means ESP lecturers are to master the basic knowledge of the target domain, then proceed to abstracting linguistic features of the given discourse (Dudley-Evans and St John 1998). Once those features are extracted, there need to be made a corpus of relevant, up-to-date, useful and usable teaching and learning material. It is made primarily of the latest scientific/professional literature or documents, which again is upon the lecturer to examine and keep following the changing and/or innovative trends which is an additional difficulty. ESP professionals thus have to engage in self-education in order to develop their own perceptions of effective teaching in those to them alien environments.

Basically, in finding a way around the language content and syllabus design, teachers decide on "plausibility" (Prahbu 1987: 103) regarding the content, structuring, methodology of each class, but also of the whole syllabus, stemming from the previously researched both learners' and perspective employers' directions, plus being fully alert to complex "ethical" questions interwoven in deciding upon learners' needs, as Belcher warns (Belcher 2004). In this environment, feedback that is reactive or incidental, as brought upon the exhibited language performance on the part of the students in class is highly valuable (Spada \& Lightbown 2008), as the syllabus of this type cannot be fully and strictly designed ahead. Some units may appear as obviously needed during the course resulting from the reactive attention during classroom interaction and subsequent immediate identification of needs and interests (Ellis 2012: 271-306). An ESP lecturer therefore needs necessarily to be engaged in constant professional development to keep pace with the advancements in the domain science and profession. This subsumes informed reflective professional capability 
(Hedgcock 2002) to critically discern emerging context-dependent discourses, and respond by creating appropriate linguistic interactive learning material and practice that corresponds to new circumstances.

Most of the professions are exposed to similar circumstances - the changing professional and scientific universe, but then, that is followed by adequate professional trainings for the employers who in their work are required to adapt to the new circumstances so as to maintain the high level of performativity. Yet, this is not the case with ESP lecturers, though the need for their in- but also pre-service trainings is obvious. Such trainings are far too scarce in worldwide terms, either as parts of universities' curriculum or independent, specialized teacher trainings. Instead, in the literature, and teaching practice, there is only the concept of teacher self-development (Richards 1998: xiv), which goes in line with ESP teachers' selfeducation. This is proclaimed and constantly insisted upon as inherent characteristic of this line of English language teaching.

\section{3. (NON)AVAILABILITY OF ESP TEACHER TRAINING}

Yet, here, we identify central paradoxical situation. The approach to ELT that is most performativity oriented does not receive adequate attention from academia and relevant publishing houses. We take these two stakeholders in the educational process as the main proponents of the mainstream trends in teaching/learning. There are far too scarce ESP courses integrated into English philology studies curricula. To our knowledge, in Europe there is Mykolas Romeris University, Vilnius, Lithuania, which offers a Bachelor degree program on English for Specific Purposes https://stdb.mruni.eu/siulomu_programu_sarasas.php?l=en, and University of Durham, UK, with a master's degree program https://www.dur.ac.uk/ englishlanguage.centre/postgraduate/matesol/esp/, Stockholm University, Sweden, with a course in LSP at master's degree https://www.english.su.se/education/courses/secondcycle/languages-for-specific-purposes-theory-and-practice-enfs75-7-5-credits-1.62980.

Occasionally, some universities in UK offer particular ESP courses, yet not as graduate programs, and those mostly on demand.

The policy of most academic English language departments is to prepare students with sound basic linguistic knowledge and knowledge of language teaching methodology. No English department can forecast or simulate all possible different situations in which future linguists may find themselves. But, what can be offered, and we claim is much needed, are introductory ESP courses that can provide students with the insight into how to abstract, delineate major linguistic features of some professional linguistic situation. Students of English language and linguistics need to get themselves familiar with what the scientific/professional domain English courses are needed for, how to assess the linguistic and communicative requirements of the target environment, create course material, design teaching and assessment strategies. This sort of expertise provided for in academia would prepare them to independently work in the realm of ESP.

At academia in Europe, but wider as well, ESP lecturers are either affiliated with a faculty at which they teach, or with a sort of language service unit at the university level from where they get assigned courses to teach at various faculties. In both cases, they are removed from the English language and linguistics department. Moreover, it is common that at the faculties where they teach they are the only ESP lecturer. This scatterdness and physical distance from the alma mater are massive causes for rare and insufficient 
communication with the department of English language - in both directions. There is no constant, day to day exchange of professional practice experiences, insights, challenges, problems, their resolutions, and alike. Yet, although left without constant feedback from ESP lecturers, it appears English language departments do not perceive the need for ESP in the curriculum, or are inert to it.

These departments educate future English language professionals who unless find job posts in primary schools, will go to work in secondary schools where ESP is present alongside GE, or to universities, or companies of various profiles, in all of which sound mastery of ESP is imperative. So, there are English language graduates who teach adult professionals in higher education and in life-long educational settings, and those who work in business sector, none of whom with adequate academic training in ESP. This is a striking fact as ESP is directly related to the economic sector of the society for which those English language departments educate future English language teachers.

\section{ATTITUDE OF PUBLISHING HOUSES TOWARDS ESP}

Although ESP is a widely needed form of adult ELT worldwide, due to the very specific situation regarding the design of teaching/learning materials aimed for a highly limited target audience, publishing houses have little interest in publishing ESP material other than very general, introductory, the one that can be subsumed under the category of general scientific education. Yet, those same publishing houses cannot be 'blamed' for this attitude. ESP textbooks, or better to say teaching material, if designed to closely adhere to the specificities of a particular domain setting, is questionable for bringing revenue. Such material is almost idiosyncratic, that is barely applicable in another professional environment, and only (small) excerpts are usable for practitioners working in the same line of domain, yet in different actual circumstances. On the other hand, indepth, high quality ESP textbooks can well be found in various, globally scattered universities publishing units. Beyond being shared usually among colleagues with whom the authors cooperate, those books remain unknown, unheard of.

The proof that ESP research is well developed and thriving are a few international ESP journals, not many, yet well recognized, with regular editions, and submissions from worldwide over. We understand this, we may say phenomenon, as a sign that ESP is gaining grounds and that the practitioners need more and more space to present their work. These journals have a crucial part in disseminating the knowledge of the relevance of ESP in responding to contemporary educational requirements, and they could play a significant role in raising the awareness of educational policy makers towards establishing more ESP training courses for future practitioners, and therefore establishing ESP as a discipline in itself.

\section{VEHICLES OF CHANGE}

English for Specific Purposes is tacitly struggling for recognition of its prevailing relevance over General English in English Language Teaching of adult learners, starting from secondary education, focusing on higher education, and being equally relevant for life-long learning. The basis for this is the overall focus of contemporary educational policies at the referred to levels towards efficient and high performativity in professional 
and scientific world. With such focus and environment, given that English (General English) is learnt and mastered well enough before entering professionally oriented level of education, the conduit of knowledge are linguistic skills directly usable in the target domain of business and/or science. The reasons for the current, insufficiently acknowledged relevance of ESP relate to the attitude of educational institutions who are unfamiliar, reluctant, or refusing to implement ESP courses, resulting in a huge lack of appropriately trained lecturers, all this leading to general unawareness of the potential of ESP professionals to enhance and assist business and scientific domains. It is most often up to individual ESP practitioners with insight and strength and willingness to present the case of the need of ESP to authorities and persevere in argumentation for inclusion of this approach into curriculum (Guest, 2016; Estaji, Rahmini, 2014). There is also an issue of ESP teaching/learning material base that is by its nature restricted to specified groups of users, which does not make it suitable for other settings. This is the reason why publishing houses resort to ESP only at a general level. The potential for change is promotion through ESP relevant publications and events, all of which allow ESP lecturers to voice their presence and expertise. Yet, the major contribution in recognizing and establishing ESP is to come from educational institutions which will hopefully adjust to the required performability of the contemporary professional environment, and respond to those by training students in the domain English language for further fostering greater employability and research skills.

\section{REFERENCES}

Belcher, D. (2004). Trends in Teaching English for Specific Purposes. New York: Palgrave Macmillan.

Dudley-Evans, T., St John, M. (1998). Developments in ESP: A multi-disciplinary approach. Cambridge: Cambridge University Press.

Ellis, N. C. (2012). "What can we count in language, and what counts in language acquisition, cognition, and use?" In S. Th. Gries \& D. S. Divjak (Eds.) Frequency effects in language learning and processing. Vol. 1, 7-34. Berlin: Mouton de Gruyter.

Estaji, M., Rahmini, A. (2014). "Revisiting the ESP Teachers' Perception of Resilience: A Call for More Professional Development of Teachers". In Asian ESP Journal, Vol. 10, No 1, 32-63 file:///D:/!\%20Download/09115600.pdf Accessed May, $12^{\text {th }}, 2019$.

Guest, M. (2016). "Overcoming Institutional Barriers to Establishing an ESP Programme: A Case Report in Japan." In Asian ESP Journal, Vol. 12, No 3: 7-23 file:///D:/!\%20 Download/79791600\%20(1).pdf Accessed January, 19 ${ }^{\text {th }}, 2019$.

Mackay, R., Mountford, A. (Eds.) (1978). English for Specific Purposes. London: Longman.

Hedgcock, J. S. (2002). "Facilitating Access to Communities of Practice in Language Teaching: Toward a Socioliterate Approach to Teacher Education". In The Modern Language Journal, Vol. 86, No. 3: 299-317.

Prahbu, N. S. (1987). Second Language Pedagogy. Oxford University Press.

Richards, J. C. (1998). Beyond Training. Cambridge University Press.

Spada, N., Lightbown, P. M. (2008). "Form-Focused Instruction: Isolated or Integrated?" in TESOL Quarterly, Volume 42, Issue 2: 181-207. 